\title{
The Lean Supply Practices in the Garments Manufacturing Companies in Jordan
}

\author{
Ziad Moh'd. Ali Smadi \\ Assistant Professor, Department of Business Administration, Faculty of Business \& Finance \\ Al-al-Bayt University \\ Tel: 962-79-521-9177_E-mail: ziad34@hotmail.com
}

Received: September 27, 2011

Accepted: February 10, 2012

Published: April 1, 2012

doi:10.5539/ibr.v5n4p88

URL: http://dx.doi.org/10.5539/ibr.v5n4p88

\begin{abstract}
The purpose of this study is to identify the extent of applying lean supply practices in the Garments manufacturing companies in Jordan, five variables were selected to be studied since the researcher believes that, they represent the lean supply concept, these variables are, Supplier feedback, Just in time delivery by suppliers, Supplier development, Customer involvement and Facilitation of just in time production, a survey questionnaire was distributed for that purpose to those who occupy managerial positions in those companies, the study revealed that the Garments Manufacturing Companies in Jordan adoption to the lean supply practices is considerably high at all aspects, except for supplier development which was given average rating.
\end{abstract}

Keywords: Lean supply, Lean productions, Garment industry, Jordan

\section{Introduction}

According to literature the term lean means getting rid of what is unneeded, in other words is to cut fat, for manufacturing environment, lean means to keep inventory, waste, defects, and time required, at the minimal level. Womack et al. (1991) came up with the following definition for the lean production, which put emphasis on the input and output dimensions of manufacturing, based on his view, Lean production is "lean" because it uses less of everything compared with the other traditional manufacturing method, such as mass production, it may use half the human effort in factory, half the manufacturing space, half the investment in tools, half the engineering hours to develop a new product in half time. Also, it requires keeping far less than half the needed inventory on site, results in many fewer defects, and produces a greater and ever growing variety of products.

Lean production is an approach that encompasses a wide array of managerial practices, which may include, just-in-time (JIT), quality principles, team work values, advanced manufacturing methods, good supplier management, and many more principles in an integrated system. The essence of lean production is that, these managerial practices can work interchangeably to create a high quality system that produces products at the pace of customer demand with little or no waste.

As competition is the major slogan of the 21 century, the purchasing and supply function has become a key issue for most companies, leading to the recognition to its strategic relevance (Dyer, 1996; Carter \& Narasimhan, 1996; Narasimhan \& Das, 1999; Mol, 2003).

Global supply of fashion clothes suffer the undesirable combination of changing demand, short life cycles and long supply lead times, which often results in excessive obsolescence or shortages (Fisher et al., 1994), hence, Jordan apparel industry is not an exception since it experiences problems that require solutions based on lean inventory and supply production systems, which makes the research problem a very relevant and timely one.

Jordan's garment and textile industry is a heavy hitter in the world markets; Jordan has 13 QIZ with over 50 factories operating inside of these zones (QIZ, 2005).

There are agreements that have influenced the garment and textile industry in Jordan include the General Agreement on Tariffs and Trade (GATT), Jordan-European Union Association Agreement, and the General Agreement on Services (GATS); all of which make Jordan a strong competitor in the world garment and textile market (Jordan FTA, 2009).

Over 55,000 people are employed in the textile and garment industry in Jordan which is about one third of Jordan's industrial labor force (Growth of MENA industries, 2007). In 2004, the Jordan Economic \& Commerce Bureau 
states textiles and apparels were one of their main exports not only to the United States but to the world. Over $30 \%$ of Jordan's total exports are from textile and garment manufacturing (Apparel \&Textile, 2005).

\section{Related Literature and Studies}

Lean production is sometimes called the Toyota production system, with the Toyota Motor Company's Eiji Toyoda and Taiichi Ohno given credit for its approach and innovation. There are four underlying principles to TPS (Spear, 2004):

- Work shall be completely specified as to contend, sequence, timing, and outcome.

- Every customer-supplier connection, both external and internal, must be direct and specify personnel, methods, timing, and quantity of goods and service provided.

- Product and service flows must be simple and direct, goods and services must be directed to specific person or machine.

- Any improvement in the system must be made in accordance with the scientific method at the lowest possible level in the organization.

Lean production is being supported by Just-in-time, which is a philosophy of continuous and forced problem solving, lean production supplies the customer with exactly what the customer wants, when the customer wants it, without waste, through continuous improvement. Lean production is driven by the pull of the customer's order. Just-in-time is a key ingredient of lean production. When implemented as a comprehensive manufacturing strategy, Just-in-time and lean production sustain competitive advantage and result in greater overall returns (Fullerton \& Watters, 2001). However, the concepts and techniques under the lean label were basically the same as those of just-in-time a decade earlier (2007).

Companies store inventories to enable continuous deliveries and overcome problems such as demand variability, unreliable deliveries from suppliers, and breakdowns in production processes. However, there is a need to maintain inventories at the minimum level because excess inventories would require more valuable spaces and result in higher carrying costs. Moreover, they accumulate the risk of "products becoming obsolete". Excess inventories are seen as "evils" because they hide problems such as defects, production imbalances, late deliveries from suppliers, equipment down time and long setup time (Liker, 2004).

Built up inventory is a waste of resources and an expense. The Toyota Production System evolved into just-in-time production (JITP), and is at present known as lean production. JITP is lean production (DeGarmo, Black \& Kohser, 1999; Nicholas, 1998; Rothenberg et al., 2001).

JITP's mission is "to reduce inventory slowly, identify problems, then change policies and practices to remove problems, having done so, then reduce inventory a little bit more" (Nicholas, 1998).

Lean production is most frequently associated with elimination of waste commonly held by firms as excess inventory or excess capacity (machine and human capacity) to ameliorate the effects of variability in supply, processing time, or demand. According to Little's law (Anupindi et al., 1999), the most important source of waste is inventory. Inventory in the form of work-in-progress is especially wasteful, since it hides problems and keeps problems from getting solved. However, since inventory exists for a reason, the causes behind the existence of inventory must be removed first. Important ways of reducing the need for inventory are, to reduce set-up times, use preventive maintenance to reduce machine downtime, and change layouts to reduce transportation distances for parts (Ahlstrom, 1998).

There are three bundles that Lean Manufacturing is made off; namely JIT (with items such as JIT delivery, frequent supplier delivery, kanban pull systems, small lot sizes, and so on), TQM (with items like statistical process control, poka yoke, equipment problem- solving, and so on) and HRM (with items such as employee encouragement, multiple task training, flat organization structure, and so on) (Dal Pont et al., 2008).

The role of purchasing as one of the determinants of lean production has evolved dramatically in the recent past, due to both the increased level of outsourcing and the globalization of the business environment, requiring the development of advanced supply management capabilities (Olsen \& Ellram, 1997).

In order to create a strong supply chain, the logistics between successive partners need to be integrated. Many researchers regard this as important for supply chain operations in general (Vaart \& Donk, 2008).

The Lean supply model (Lamming, 1993; Womack \& Jones, 1996), which was developed in the automotive industry as a way to manage complex, tiered networks of suppliers with the goal of reducing costs while ensuring high quality. This model prescribes long-term relationships between customers and suppliers, based upon a close 
integration of both physical and information flows, adopting practices such as EDI exchange, cost transparency, JIT with Kanban, co-design, etc.

Lean manufacturing requires that not only should technical questions be fully understood, but existing relationships between manufacturing and the other areas of the firm should also be examined in depth, as should other factors external to the firm (Womack \& Jones, 1994).

More recently lean manufacturing (Womack et al., 1990) and lean thinking (Womack \& Jones, 1996) have demonstrated the broad potential of the elimination of waste in improving business performance. The emphasis on waste elimination is closely associated with reduced inventory and one of the key concepts is enforced problem solving, which is very effectively portrayed by the ubiquitous ship and rocks analogy. As the inventory is lowered, the sources of waste are exposed in the form of late delivery, poor quality conformance, long set-ups, unreliable processes, etc. The elimination of these sources of waste and unevenness enables the inventory to be lowered further without impeding material flow.

According to Womack and Jones (1996), "The critical starting point for lean thinking is value...defined by the ultimate customer...only meaningful when expressed in terms of a specific product...Value is created by the producer." He also added; product flow is managed by customer demand, just-in-time, since upstream production is only initiated when end customers purchase products downstream, triggering the pulling of products from producers through suppliers.

A study that empirically explores the supply strategies of European manufacturing firms within the third edition of the International Manufacturing Strategy Survey was conducted by (Cagliano et.al, 2004), they identified four clusters on the basis of the supplier selection criteria and the integration mechanisms adopted. Two clusters are similar to the Lean and the Agile models, while the other two are more traditional supply strategies, even if they present some advancement compared to the arm's-length supply model. The strategies are then described in terms of contingent and structural factors and manufacturing performance. Lean and Agile strategies outperform the other clusters on many dimensions, while no significant difference emerges between the two in terms of performance.

Corsten and Will (1995) described lean production tenets as kanban systems, standardized work, teamwork, just-in-time inventory practices, continuous production flows, zero defects, integrated product development, continuous process improvement, and production islands.

Womack and Jones (1996), confirmed that, product flow is managed by customer demand and just-in-time, since upstream production is only initiated when end customers purchase products downstream, triggering the pulling of products from producers through suppliers. Pull-systems are achievable mainly through the lean manufacturing inventory management concept of kanbans/production signaling, and by co-locating functions into cellular structures to minimize travel, waiting, and inventory requirements. In addition, trailer arrival, loading, and unloading processes are standardized to facilitate frequent, just-in-time deliveries.

In their research on measuring the lean maturity level in manufacturing firms in turkey, (Satuglu \& Durmusoglu, 2007) concluded that, Suppliers Relationship Management was determined to be the most successful Lean Production Technique, and Kanban System was determined to be the least successful Lean Production technique. Because the manufacturing companies in Turkey could not be able to leave the Push Production Control System. In addition they hold excessive inventories in order to provide just-in-time deliveries.

In their research on the Lean Assessment in Organizations: An Exploratory Study of Lean Practices by Electronics Manufacturers, (Doolen \& Hacker, 2005), found that, while electronic manufacturers have implemented a broad range of lean practices, the level of implementation does vary and may be related to economic, operational, or organizational factors.

Sohal (1996) examined Trico Australia's successful implementation of lean production. Trico Australia is a producer of windshield wiper products. Upon the successful implementation of lean production, Trico Australia experienced reductions in tooling setups, increases in stock turn over, and new product development. (Young, 1992) narrowed lean production tenets to kaizen, kanban systems, total quality control, just-in-time purchasing and secondary controls.

A survey examined 65 conceptual studies, 25 empirical studies, and 15 mathematical studies. It concluded that the major tenets of the just-in-time (lean production) philosophy are the elimination of waste, a sound production strategy, a program promoting quality control and assurance, a program promoting continuous improvement, a strong management commitment, employee participation, and vendor participation (Ramarapu et.al,1995).

TQM and JITP (lean production) support each other in the reduction of inventory, shortening of cycle times, reducing of lot sizes, and the flow of material through the production system. "TQM and JITP (lean production) can 
function effectively alone, however when applied together, synergies result that can lead to further performance improvements" (Flynn et al., 1995).

\section{Research Problem}

With lower trade barriers, the global textile and Garments industry during the last 10 years has grown more competitive, prices have fallen and margins are thinner. The average Garment import price in Jordan's largest market, the US, fell by almost $18 \%$. This has meant increased pressure on buyers and manufactures to produce at lower cost and at faster speed, though most buyers remain committed to Jordan today, but some have started removing orders as a direct result of increased compliance cost (World Bank, 2008).

Lean supply adoption can be one of the solutions for Jordan to be competitive on the global level. That is why the research sought to find an answer for the main research problem which is: Is there a lean supply environment at the Garment Manufacturing Companies in Jordan.

\section{Research Objective}

Taking into consideration the above mentioned problem, the research objective is to find out, the degree of the practice of the lean supply concept at the Garment Manufacturing Companies in Jordan, in terms of:

1. Supplier Feed back

2. Just in time delivery by suppliers

3. Supplier development

4. Customer involvement

5. Facilitation of just in time production

\section{Research Hypothesis}

The study tackled different lean supply practices concepts. Therefore; the main null hypothesis of the study is:

H01: The Garments manufacturing companies in Jordan practice Lean Supply concept at a very low level.

From the main hypothesis the researcher derived the following sub-hypothesis:

H0a: The Garments manufacturing companies in Jordan do not pay attention to the Supplier feedback.

H0b: The Garments manufacturing companies in Jordan do not ask suppliers to deliver based on the Just in time system.

H0c: The Garments manufacturing companies in Jordan do not get involved in activities or programs that lead to supplier development.

H0d: The Garments manufacturing companies in Jordan do not involve customer in the production process.

H0e: The Garments manufacturing companies in Jordan do not Facilitate the just in time production.

H02: There are no significant differences among the answers of the respondents of the study in relation to their demographic profile.

\section{Research Methodology}

A descriptive and analytical methods were used in this study, in addition to that, the researcher utilized partially a construct developed by (shahna \& ward, 2007) to measure the level of the lean supply practices, the researcher also sought the feedback and the advice of the people from the Garments industry and some academicians about the suitability of the research instrument, who confirmed that the instrument is fit to the garments manufacturing companies environment setting, at the same time they selected only items that are relevant to the lean supply concept.

The instrument made off the following parts:

The first Part: Covers the demographic profile of the respondents.

The second part: Includes the lean supply practices such as, Supplier feedback, Just in time delivery by suppliers, Supplier development, Customer involvement and Facilitation of just in time production.

Nominal scale was used to allow the respondents to answer the questions related to their demographic profile, while likert scale was used to allow the respondents to rate their answers on the different lean supply practices, which is ranging from strongly agree as the highest while strongly disagree as the lowest. 


\subsection{Population and Sample of the Study}

A purposive sampling technique was utilized, 120 questionnaires have been distributed to employees who only occupy managerial posts in the garments manufacturing companies in the northern \& the national capital region of Jordan, 109 or $90.84 \%$ of the questionnaires were recovered, 13 or $10.84 \%$ of which were excluded for not meeting the validation requirements, hence 96 or about $80 \%$ of the questionnaires were valid for analysis.

\subsection{Data Collection Method}

A secondary source of data such as references and published and unpublished researches in the field of the lean supply has contributed to the development of the theoretical framework and allowed researchers gain more deep understanding on the topic. In addition to that Primary data were also obtained through the main instrument of the study, which is a tested research construct developed by (shahna $\&$ ward, 2007).

\subsection{Statistical Treatment}

The following statistical techniques were applied in this study:

1. Descriptive analysis such as: mean and standard deviation of the answered items of the study.

2. One sample t-test to test the main hypothesis of the study.

3. Analysis of variance one way ANOVA was used to test the second main hypothesis, which is regarding the demographic profile of the respondents. In addition Post Hoc Multiple comparisons Scheffe was also used.

4. Pearson correlation was used to measure the inter-correlation between the different lean supply practices.

\section{Data Presentation and Research Finding}

\section{Insert Table 1 Here}

Table 1 shows that most of the study respondents were males with a percentage of (58.3\%) and that is probably fair result, and the role of the female population also cannot be underestimated since they account for $41.7 \%$, in a culture that discourage the female population from working in the industrial sector.

The table also shows the age bracket of most of the respondents is less than 40 years old, which indicates the attractiveness of the industrial sector to the young workers.

Most of the study respondents are bachelor degree holders since the positions they are occupying, require professional and technical knowledge to able to make the appropriate decision.

Most of the respondents have a position of head of departments in the company with a percentage of (33.3\%).

Most the respondents have experience between 5-10 years in the company with a percentage of (54.2\%) which shows a fair degree of stability in the industrial sector in Jordan.

Most the respondents have an experience in the same position of less than 5 years, this means that, selection criteria for managerial position is based on the degree of the knowledge the worker has and not on the length of time he or she spent in the company.

Most of the industrial companies that took part in the study were of age between 10-15 years with a percentage of $62.5 \%$, which shows stability in the business environment in Jordan.

The analysis shows also most of the garments manufacturing companies are of large size with a percentage of $66.7 \%$, also they target serve international with $87.5 \%$ percentage, and most of these manufacturing companies employ more than 240 employees.

When it comes to the ownership of these industrial companies, results show that, most are owned by Non-Jordanians with a percentage of $70.8 \%$.

\subsection{Reliability Test and Analysis of the Coefficient of Internal Consistency}

Insert Table 2 Here

A reliability test the of the items in the questionnaire was conducted, the table above shows the values of coefficient of internal consistency of lean practices variables, the result is $.8765 \%$ which is acceptable since it is more than the minimum required percentage which is $60 \%$ for social science researches (Cronbach,1951).

\subsection{Answering the Main Hypothesis of the Study}

The first main problem of the study: Is there a lean supply environment at the Garment Manufacturing Companies in Jordan? To answer this question the first main Null Hypothesis was formulated, which is:

H01: The Garments manufacturing companies in Jordan practice Lean Supply concept at a very low level. 
Insert Table 3 Here

The table above shows that the highest average among these factors was the Supplier feedback, which got a rating of (4.40), this shows the extra attention that Garments manufacturing companies in Jordan pay to the supplier feedback, followed by Customer involvement got a rating of (4.33) then Just in time delivery by suppliers rated (4.22) and the lowest were Facilitation of just in time production (4.09) and the Supplier development (3.59) which are according to our scale at the medium level. The average mean for all factors turned out to be at the medium level with a rating of (4.13).

\subsubsection{Answering the First Sub Hypothesis (H0a)}

The Garments manufacturing companies in Jordan do not pay attention to the Supplier feedback.

Table 4 Presents data related to the first sub-problem, it has been ranked and classified according to the respondents rating for each item.

Insert Table 4 Here

Table 4 Shows that the overall average was 4.40 which indicates a high acceptance rating among the respondents of the study on the questions related to supplier feedback. It is also important to point out that, the item that got the highest rating is "We frequently are in close contact with our suppliers" with an average of (4.62), that is due the availability of advance information and communication technology, followed by "we frequently are in close contact with our suppliers" with an average of (4.60), but the lowest in rating was "we visit our supplier's plants regularly with a rating of (4.10)".

Insert Table 5 Here

The table above shows that the first sub-hypothesis was rejected because the t-value is more than the tabulated t$(33.746>1.96)$ and under the significance level of $(\alpha \leq .05)$, therefore the alternative hypothesis (H1) was accepted, which means that the Garments Manufacturing companies in Jordan pay attention to Supplier feedback.

The second sub-hypothesis (HOb) test: The Garments manufacturing companies in Jordan do not ask suppliers to deliver based on the Just in time system.

Insert Table 6 Here

Table 6 shows that "Suppliers provides us the appropriate quantity needed", got (4.5), which is the highest average among all items related to sub-problem no.2, and a standard deviation of (0.58), followed by, "our key suppliers deliver to plant on JIT basis" with an average of (4.29) and a standard deviation of (0.614), but the lowest with an average of (3.875) and a standard deviation of (.7847) is related to the, Suppliers are directly involved in the new product development process.

\subsubsection{Testing the Second Sub-Hypothesis}

\section{Insert Table 7 Here}

It is shown in the table above that the second sub-hypothesis was rejected, because the t- value is more than the tabulated $\mathrm{t}$ - $(22.821>1.96)$, and under the significance level of $(\alpha \leq .05)$, therefore the alternative hypothesis $(\mathrm{H} 1)$ was accepted, and that means: The Garments manufacturing companies in Jordan do ask suppliers to deliver based on the Just in time system.

\subsubsection{Testing the Third Sub-Hypothesis (H0c)}

The Garments manufacturing companies in Jordan do not get involved in activities or programs that lead to supplier development.

Insert Table 8 Here

Table 8 Shows that the overall average for the third lean supply practice is medium with an overall average of (3.597), which pertains to the nature of Garment industry which is sometimes referred to as traditional one that does not let suppliers get involved totally in the product or process development.

But the item "We have corporate level communication on important issues with key suppliers" got a high a rating of (4.458) because no company can succeed now a day without an efficient communication. Going to the items on the table above it is obvious that a high rating was also given to the item "Our suppliers are contractually committed to annual cost reductions" with an average of (4.29) and a standard deviation of (0.7386), but the lowest was "Our key suppliers are located in close proximity to our plants with a rating of (1.75) and a standard deviation of (0.9733)", this due to the fact that most suppliers are located outside of Jordan. It also should be noted that, the item "our key suppliers manage our inventory" got a medium average of (3.75) with the highest standard deviation of (1.133). 


\section{Insert Table 9 Here}

Table 9 shows that H0c was rejected because the t-value was more than the tabulated $t-(53.446>1.96)$ under the significance level of $(\alpha \leq .05)$ therefore the alternative hypothesis (H1) was accepted, which means that the suppliers get involved in activities or programs that lead to supplier development.

\subsubsection{Testing the Fourth Sub-Hypothesis (H0d)}

The Garments manufacturing companies in Jordan do not involve customer in the production process. Insert Table 10 Here

Table 10 Shows that the overall average for Customer involvement is (4.333), which is considered a high response rating, this confirms the sensitivity of the Garments industry that calls for getting the customer involved and keeping in touch with him, because this type of industry is effected heavily by trends and styles, but among items, the highest rating went to the item; We frequently are in close contact with our customers, with a rating of 4.625 followed by, Our customers give us feedback on quality and delivery performance with an average of (4.5). The lowest equal rating of (4.1250) went to the items "Our customers frequently share current and future demand information with marketing department" and "We regularly conduct customer satisfaction surveys", though that rating is considered the lowest but it is still high.

\section{Insert Table 11 Here}

The table 11 shows that the fourth sub-hypothesis was rejected because the t-value was more than the tabulated t$(39.188>1.96)$ under the significance level of $(\alpha \leq .05)$ therefore the alternative hypothesis (H1) was accepted, which means that The customers are involved and they participate in product development process and their opinions are considered as necessary production data.

Testing the fifth sub-hypothesis (H0e): The Garments manufacturing companies in Jordan do not facilitate Just in Time production.

\section{Insert Table 12 Here}

The table above shows that the overall average for all items concerning the fifth sub- problem is (4.093), which represent a high response rate. The highest rating went to item number (1) which is Production is "pulled" by the shipment of finished goods, the lowest average went to the query related to "We use Kanban, squares, or containers of signals for production control" with an average of (3.75). The highest standard deviation with an average of (1.19) to the query related to "We use a "pull" production system" this represent a high variation in answers.

\subsubsection{Testing the Fifth Sub-Hypothesis}

Insert Table 13 Here

The table 13 shows that the fifth sub-hypothesis was rejected because the t-value was more than the tabulated t$(19.26>1.96)$ under the significance level of $(\alpha \leq .05)$ therefore the alternative hypothesis (H1) was accepted, which means that there is a facilitation of just in time production in the Garments Manufacturing Companies in Jordan.

The second main Null Hypothesis: There is no significant difference among the answers of the respondents pertains to their demographic profile.

In order to prove or reject this hypothesis one way ANOVA was used which is shown in the table below.

\section{Insert Table 14 Here}

Table 14 shows differences among the answers of the sample of the study pertains to their demographic profile, because the level of significance is less than $0.05(.000<.05)$, and indicates a high difference among the answers of the of the respondents regarding the Lean supply practices in their Manufacturing company. The F value is $>1.96$ in all factors, which implies that, workers have different opinions regarding the Lean supply practices.

\subsubsection{Correlation between the Variables of the Study}

\section{Insert Table 15 Here}

The table above shows the correlation between the different variables of the study, it is noted that almost all factors has a very high correlation accept between Supplier development and Customer involvement and between the Just in time delivery by suppliers and Supplier development with a very low correlation of about $19 \%$ only, with a confidence level of about .059 which is greater than the significant level of .05 . Another weak correlation is between 
supplier feedback and Supplier development with a significance level of $25.2 \%$, which represents a very low correlation

\section{Research Conclusion}

The Garments Manufacturing Companies in Jordan adoption to the lean supply practices is considerably high at all aspects, except the supplier development which was rated average.

They are regularly in close contact with their suppliers, furthermore, they are working on building long relationships with their suppliers, because they believe that, they can be the major key of success as well as failure. Aside from that suppliers are given feedback concerning quality and delivery to avoid any future problem, this result is similar to the finding of (Sohal, 1996).

In terms of the Just in time delivery, majority of the respondents agreed that get the right quality and quantity of materials they need and when they are needed, but they issue suppliers certificate based on some criteria through which they can classify them, which can lead to better performance (Flynn et al., 1995).

The Practice of supplier development was rated average because their Suppliers are not located in close proximity with the Garments companies, but when it comes to cost reduction, most of the respondents believe, suppliers are committed to that, which in return will lead to optimum resource utilization and improved process efficiency (Beamon \&Ware, 1998). Besides, the Garment companies maintain good communication with their suppliers at the corporate level.

Garments manufacturing companies are in close contact with their customers, whom they seek to satisfy their psychological need more than their physical need, since trends and fashion are major determinants of clothing production. That also requires Garment companies to get regular feedback on quality and delivery performance, which allow customers to play active role in products offering.

The Garments manufacturing companies in Jordan facilitate the Just in time production, because production is conducted according to Customers orders which are delivered to right after manufacturing.

Even inside the plants no in process inventory is accumulated because Production at stations is "pulled" by the current demand of the next station.

\section{Limitations}

This paper is the first of its kind that explores an issue such as Lean supply, thus the researcher had a difficulty in finding a similar studies which have been applied to similar or different industries or countries, thus he relied mostly on related studies on the topic of lean production.

The study also covers only garments companies operating in Jordan, which means the findings and conclusions, can be only applied to the target population of the study.

\section{Recommendations for Future Researches}

The researcher recommends future scholars to explore the broader venue of lean production and relating it to variables such as, quality, flexibility and competitiveness in particular and corporate performance in general.

It is also recommended that other industrial sectors will be explored, especially those in need and have the potentials to do so, such as, Electronic, Pharmaceutical, and Furniture sectors.

The Garments Sector is recommended to conduct researches regularly on Lean production, to make it sure that their sector is moving on the right track of competiveness.

\section{References}

Ahlstrom, P. (1998). Sequences in the implementation of lean production. European Management Journal, 16, 327-334. http://dx.doi.org/10.1016/S0263-2373(98)00009-7

Anupindi, R., Chopra, S., Deshmukh, S. D., Van Mieghem, J. A., \& Zemel, E. (1999). Managing Business Process

Flows. Upper Saddle River, N.J.: Prentice Hall.

Apparel, \& Textiles, J. E. (2005). Retrieved March 19, 2009 from Jordan Economic \& Commerce Bureau: http://www.jordanecb.org/apparel_textiles.shtm

Beamon, B. M., \& Ware, T. M. (1998). A process quality model for the analysis, improvement and control of supply chain systems. International Journal of Physical Distribution \& Logistics Management, 28, 704-715. http://dx.doi.org/10.1108/09600039810248127 
Cagliano, R., Caniato, F., \& Spina, G. (2004). Lean, Agile and traditional supply: how do they impact manufacturing performance?. Journal of Purchasing \& Supply Management, 10, 151-164. http://dx.doi.org/10.1016/j.pursup.2004.11.001

Carter, J. R., \& Narasimhan, R. (1996). Is purchasing really strategic?. International Journal of Purchasing and Materials Management, 32(1), 20-28.

Corsten, H., \& Will, T. (1995). Integrated production concepts: Structural reasons for superior competitive performance. Management International Review, 35(1), 69-89.

Cronbach, L. J. (1951). Coefficient alpha and the internal structure of tests. Psychometrika, 16(3), 297-334. http://dx.doi.org/10.1007/BF02310555

Dal Pont, G., Furlan, A., \& Vinelli, A. (2008). Effects on performance of lean bundles. Proceedings on the $15^{\text {th }}$ EurOMA Conference. University of Groningen, The Netherlands, pp. 15-18.

DeGarmo, E. P., Black, J. T., \& Kohser, R. (1999). Materials and processes in manufacturing (8th ed.). New York: John Wiley \& Sons.

Fisher, M. L., Hamond, J. H., \& Obermeyer, W. R. (1994). Making supply meet demand in an uncertain world. Harvard Business Review, (May-June), 83-93.

Flynn, B., Sakakibara, S., \& Schroeder, R. (1995). Relationship between JIT and TQM: Practices and performance. Academy of Management Journal, 38(5), 1325-1360. http://dx.doi.org/10.2307/256860

Fulerton, R., \& Mc Watters, C., (2000). The production Performance Benefits from JIT Implementation. Journal of Operations Management, 19(1), 81-96. http://dx.doi.org/10.1016/S0272-6963(00)00051-6

Growth of MENA Industries: The Textile Clothing Sectors in Jordan. (2007). Retrieved March 17, 2009 from Menaar Economic Desk. http://www.menaar.org/index_files/Page3518

Introduction on The Jordan-EU Free Trade Agreement. Retrieved March 17, 2009 from Jordan-EU Association Agreement. http://www.joreu.jedco.gov.jo/eu_agreement.html

Lamming, R. C. (1993). Beyond Partnership: Strategies for Innovation and Lean Supply. Hemel Hempstead, UK: Prentice-Hall.

Liker, J. K. (2004). The Toyota Way: 14 Management Principles from the World's Greatest Manufacturer. New York: McGraw-Hill.

Mol, M. J. (2003). Purchasing's strategic relevance. Journal of Purchasing \& Supply Management, 9, 43-50. http://dx.doi.org/10.1016/S0969-7012(02)00033-3

Narasimhan, R., \& Das, A. (1999). An empirical investigation of the contribution of strategic sourcing to manufacturing flexibilities and performance. Decision Sciences, 30(3), 683-718. http://dx.doi.org/10.1111/j.1540-5915.1999.tb00903.x

Nicholas, J. (1998). Competitive manufacturing management: Continuous improvement, lean production, and customer-focused quality. New York: Irwin-McGraw-Hill.

Olsen, R. S., \& Ellram, L. M. (1997). A portfolio approach to supplier relationships. Industrial Marketing Management, 26, 101-113. http://dx.doi.org/10.1016/S0019-8501(96)00089-2

Qualified Industrial Zones. (2005). Retrieved March 18, 2009 from Jordan Economic \& Commerce Bureau. http://www.jordanecb.org/investment_qiz.shtm

Rachna, S., \& Ward, P. (2007). Defining and developing measures of lean production. Journal of Operations Management, 25(4), 785-805. http://dx.doi.org/10.1016/j.jom.2007.01.019

Ramarapu, N. K., Mehra, S., \& Frolick, M. N. (1995). A comparative analysis and review of JIT "implementation" research. International Journal of Operations and Production Management, 15(1), 38-49. http://dx.doi.org/10.1108/01443579510077188

Rothenberg, S., Pil, F., \& Maxwell, J. (2001). Lean, green, and the quest for superior environmental performance. Production and Operations Management, 10(3), 228-243. http://dx.doi.org/10.1111/j.1937-5956.2001.tb00372.x

Schonberger, R. J. (2007). Japanese production management: an evolution-with mixed success. Journal of Operations Management, 25(2), 403-19. http://dx.doi.org/10.1016/j.jom.2006.04.003

Shah, R., \& Ward, P. (2007). Defining and developing measures of lean production. Journal of Operations Management, 25(4), 785-805. http://dx.doi.org/10.1016/j.jom.2007.01.019 
Sohal, A. (1996). Developing a lean production organization: An Australian case study. International Journal of Operations and Production Management, 16(2), 91-102. http://dx.doi.org/10.1108/01443579610109866

Spear, S., \& Kent, B. (1999). Decoding the DNA of the Toyota Production System. Harvard Business Review, 77(5), 97-106.

Spear, S. J. (2004). Learning to lead at Toyota. Harvard Business Review, 82(5), 78-86.

Sule, I. S. M., \& Bülent, D., (2007). Measuring the lean maturity level in manufacturing firms in turkey. Journal of Industrial Engineering, 14(3), 4-14.

Van der Vaart, T., \& van Donk, D. P. (2008). A critical review of survey-based research in supply chain integration. International Journal of Production Economics, 111, 42-55. http://dx.doi.org/10.1016/j.ijpe.2006.10.011

Womack, J. P., \& Jones, D. T. (1994). From lean production to the lean enterprise. Harvard Business Review 72 , 93-104.

Womack, J. P., \& Jones, D. T. (1996). Lean Thinking: Banish Waste and Create Wealth in Your Corporation (Revised and Updated 2003 ed.). New York: Simon \& Schuster.

Womack, J. P., Jones, D. T., \& Roos, D. (1991). The Machine That Changed the World. New York, NY: Harper Collins.

World Bank Report. (2008). Competitiveness and Corporate Social Responsibility in the Jordanian Apparel Industry.

Young, S. M. (1992). A framework for successful adoption and performance of Japanese manufacturing practices in the United States. Academy of Management Review, 17(4), 677-700. http://dx.doi.org/10.2307/258804 
Table1. Distribution of the Sample of the Study

\begin{tabular}{|c|c|c|c|}
\hline Variable & Category & Frequency & Percentage (\%) \\
\hline \multirow{2}{*}{ Sex } & Male & 56 & 58.3 \\
\hline & Female & 40 & 41.7 \\
\hline \multirow{4}{*}{ Age } & Less than 30 & 36 & 37.5 \\
\hline & 30- less than 40 & 32 & 33.3 \\
\hline & 40- less than 50 & 20 & 20.8 \\
\hline & $50 \&$ above & 8 & 8.3 \\
\hline \multirow{4}{*}{ Education } & $10+2$ and less & 20 & 20.8 \\
\hline & Diploma & 20 & 20.8 \\
\hline & Bachelor & 48 & 50.0 \\
\hline & Higher education & 8 & 8.3 \\
\hline \multirow{5}{*}{ Position } & Executive/ general manager & 12 & 12.5 \\
\hline & Head of department & 32 & 33.3 \\
\hline & Production manager & 24 & 25.0 \\
\hline & Supervisor & 20 & 20.8 \\
\hline & Engineer & 8 & 8.4 \\
\hline \multirow{4}{*}{ Experience } & Less than 5 years & 24 & 25 \\
\hline & 5- less than 10 years & 52 & 54.2 \\
\hline & 10- less than 15 years & 8 & 8.3 \\
\hline & 15 years \& above & 12 & 12.5 \\
\hline \multirow{4}{*}{ Number of experience years in the same position } & Less than 5 years & 48 & 50.0 \\
\hline & 5 - less than 10 years & 32 & 33.3 \\
\hline & 10- less than 15 years & 12 & 12.5 \\
\hline & 15 years \& above & 4 & 4.2 \\
\hline \multirow{4}{*}{ Industrial company age } & Less than 4 years & 8 & 8.3 \\
\hline & 4- less than 8 years & 24 & 25.0 \\
\hline & 8- less than 12 years & 60 & 62.5 \\
\hline & 12 years \& above & 4 & 4.2 \\
\hline \multirow{2}{*}{ Size of Industry } & Large & 64 & 66.7 \\
\hline & Medium & 32 & 33.3 \\
\hline \multirow{2}{*}{ Market } & International & 84 & 87.5 \\
\hline & Local & 12 & 12.5 \\
\hline \multirow{4}{*}{ Number of employees } & Less than 60 & 4 & 4.2 \\
\hline & $60-$ less than 120 & 16 & 16.7 \\
\hline & 120- less than 240 & 12 & 12.5 \\
\hline & 240 employees \& above & 64 & 66.7 \\
\hline \multirow{3}{*}{ Ownership } & local & 28 & 29.2 \\
\hline & International & 68 & 70.8 \\
\hline & Total & 96 & 100 \\
\hline
\end{tabular}

Table 2. The Internal Consistency of Lean Supply Practices

\begin{tabular}{llll}
\hline Factors & N of Cases & N of Items & Alpha \\
\hline Supplier feedback & 96 & 6 & .7278 \\
Just in time delivery by suppliers & 96 & 4 & .8031 \\
Supplier development & 96 & 6 & .7797 \\
Customer involvement & 96 & 7 & .6277 \\
Facilitation of just in time production & 96 & 4 & .7156 \\
Reliability for all & .8765 & & \\
\hline
\end{tabular}


Table 3. Descriptive Statistics for All Factors of Lean Supply Practices

\begin{tabular}{lllll}
\hline Factors & N & Mean & Std. Dev. & Std. Err. Mean \\
\hline Supplier feedback & 96 & 4.4028 & .40729 & .0416 \\
Just in time delivery by suppliers & 96 & 4.2292 & .52774 & .0539 \\
Supplier development & 96 & 3.5972 & .65946 & .0673 \\
Customer involvement & 96 & 4.3333 & .33337 & .0340 \\
Facilitation of just in time production & 96 & 4.0938 & .55636 & .0568 \\
Total average & $\mathbf{4 . 1 3 1 3}$ & & & \\
\hline
\end{tabular}

Table 4. Sub-Problem No. 1

\begin{tabular}{llllll}
\hline Q & Supplier feedback & N & Mean & Std. Deviation & Rank \\
\hline 1 & We frequently are in close contact with our suppliers & 96 & 4.6250 & .60263 & 1 \\
2 & Our suppliers visit our plants regularly & 96 & 4.2813 & .62750 & 4 \\
3 & We visit our supplier's plants regularly & 96 & 4.1042 & .81408 & 5 \\
4 & We give our suppliers feedback on quality and delivery performance & 96 & 4.3854 & .62188 & 3 \\
5 & We strive to establish long-term relationship with our suppliers & 96 & 4.4271 & .69198 & 2 \\
& Total average & $\mathbf{4 . 4 0 2 8}$ & & & \\
\hline
\end{tabular}

Table 5. The First Sub-Hypothesis Test One-Sample Test

\begin{tabular}{lllllll}
\hline \multirow{2}{*}{ Lean supply factor } & \multirow{2}{*}{} & df & Sig. (2-tailed) & \multirow{2}{*}{ Mean Difference } & \multicolumn{2}{c}{ 95 \%Confidence Interval of the Difference } \\
\cline { 6 - 7 } & & & & & Lower & Upper \\
\hline Supplier feedback & 33.746 & 95 & 0.00 & 1.4028 & 1.3203 & 1.4853 \\
\hline
\end{tabular}

Note: Test Value $=3, \alpha \leq 0.05$.

Table 6. Sub-Problem No. 2

\begin{tabular}{llllll}
\hline No & Just in time delivery by suppliers & N & Std. Deviation & Mean & Rank \\
\hline 1 & Suppliers provides us the appropriate quantity needed & 96 & .58038 & 4.5000 & 1 \\
2 & Our key suppliers deliver to plant on JIT basis & 96 & .61416 & 4.2917 & 2 \\
3 & Suppliers are directly involved in the new product development process & 96 & .78472 & 3.8750 & 4 \\
4 & We have a formal supplier certification program & 96 & .66491 & 4.2500 & 3 \\
& Total average & $\mathbf{4 . 2 2 9 2}$ & & \\
\hline
\end{tabular}

Table 7. One-Sample Test

\begin{tabular}{lllllll}
\hline Lean supply factor & \multirow{2}{*}{} & df & Sig. (2-tailed) & $\begin{array}{l}\text { Mean } \\
\text { Difference }\end{array}$ & & \multicolumn{2}{c}{ 95 \%Confidence Interval of the Difference } \\
\hline $\begin{array}{l}\text { Just in time delivery } \\
\text { by suppliers }\end{array}$ & 22.821 & 95 & 0.00 & 1.2292 & 1.1222 & Upper \\
\hline
\end{tabular}

Note: Test Value $=3, \alpha \leq 0.05$.

Table 8. Sub-Problem No. 3

\begin{tabular}{llllll}
\hline Q & Supplier development & N & Mean & Std. Deviation & Rank \\
\hline 1 & Our suppliers are contractually committed to annual cost reductions & 96 & 4.2917 & .73866 & 2 \\
2 & Our key suppliers are located in close proximity to our plants & 96 & 1.7500 & .97333 & 5 \\
3 & We have corporate level communication on important issues with key & 96 & 4.4583 & .91671 & \\
& suppliers & & & & \\
4 & We take active steps to reduce the number of suppliers in each category & 96 & 3.5833 & .95880 & 4 \\
5 & Our key suppliers manage our inventory & 96 & 3.7500 & 1.13323 & 3 \\
6 & We evaluate suppliers on the basis of total cost and not per unit price & & 3.7500 & .97333 & 3 \\
& Total average & $\mathbf{3 . 5 9 7 2}$ & & & \\
\hline
\end{tabular}


Table 9. Testing the Third Sub-Hypothesis One Sample Test

\begin{tabular}{llllllc}
\hline \multirow{2}{*}{ Lean supply factor } & \multirow{2}{*}{$\mathbf{t}$} & \multirow{2}{*}{ df } & \multirow{2}{*}{ Sig. (2-tailed) } & $\begin{array}{l}\text { Mean } \\
\text { Difference }\end{array}$ & & \multicolumn{2}{c}{$\mathbf{9 5}$ \%Confidence Interval of the Difference } \\
\cline { 5 - 7 } & & & Lower & Upper \\
\hline Supplier development & 53.446 & 95 & 0.00 & 3.5972 & 3.4636 & 3.7308 \\
\hline
\end{tabular}

Note: Test Value $=3, \alpha \leq 0.05$.

Table 10. Sub-Problem No. 4

\begin{tabular}{llllll}
\hline Q. & Customer involvement & N & Mean & Std. Dev. & Rank \\
\hline 1 & We frequently are in close contact with our customers & 96 & 4.6250 & .48666 & 1 \\
2 & Our customers visit our plants & 96 & 4.2917 & .61416 & 4 \\
3 & Our customers give us feedback on quality and delivery performance & 96 & 4.5000 & .50262 & 2 \\
4 & Our customers are actively involved in current and future product offerings & 96 & 4.4583 & .57887 & 3 \\
5 & Our customers are directly involved in current and future product offerings & 96 & 4.2083 & .70958 & 5 \\
6 & Our customers frequently share current and future demand information with & 96 & 4.1250 & .78472 & 6 \\
& marketing department & & & & \multirow{2}{*}{6} \\
7 & We regularly conduct customer satisfaction surveys & 96 & 4.1250 & .44129 & \\
& Total average & 4.3333 & & & \\
\hline
\end{tabular}

Table 11. Testing the Fourth Sub-Hypothesis One-Sample Test

\begin{tabular}{lllllll}
\hline Lean supply factor & $\mathbf{t}$ & df & Sig. (2-tailed) & $\begin{array}{l}\text { Mean } \\
\text { Difference }\end{array}$ & \multicolumn{2}{c}{ 95 \%Confidence Interval of the Difference } \\
\cline { 6 - 7 } $\begin{array}{l}\text { D- Customer } \\
\text { involvement I }\end{array}$ & 39.188 & 95 & $0 . .000$ & 1.3333 & 1.2658 & Upper \\
\hline
\end{tabular}

Note: Test Value $=3, \alpha \leq 0.05$.

Table 12. Sub-Problem No. 5

\begin{tabular}{llllll}
\hline Q. & Facilitation of just in time production & N & Mean & Std. Deviation & Rank \\
\hline 1. & Production is "pulled" by the shipment of finished goods & 96 & 4.3542 & .72517 & 1 \\
2 & $\begin{array}{l}\text { Production at stations is "pulled" by the current demand of the next } \\
\text { station }\end{array}$ & 96 & 4.2396 & .77792 & 2 \\
3 & We use a "pull" production system & 96 & 3.7708 & 1.19190 & 3 \\
4 & We use Kanban, squares, or containers of signals for production control & 96 & 3.7500 & 1.04630 & 4 \\
& & & & \\
\hline
\end{tabular}

Table 13. One-Sample Test

\begin{tabular}{lllllll}
\hline Lean supply factor & $\mathbf{t}$ & df & Sig. (2-tailed) & $\begin{array}{l}\text { Mean } \\
\text { Difference }\end{array}$ & \multicolumn{2}{c}{ 95 \%Confidence Interval of the Difference } \\
\hline $\begin{array}{l}\text { Facilitation of just in } \\
\text { time production }\end{array}$ & 19.262 & 95 & 0.000 & 1.0938 & .9810 & Upper \\
\hline
\end{tabular}

Note: Test Value $=3, \alpha \leq 0.05$. 
Table 14. Analysis of Variance (ANOVA)

\begin{tabular}{|c|c|c|c|c|c|c|}
\hline variable & & Sum of Squares & df & Mean Square & $\mathbf{F}$ & Sig. \\
\hline \multirow{3}{*}{ Sex } & Between Groups & 17.183 & 26 & .661 & 7.414 & .000 \\
\hline & Within Groups & 6.151 & 69 & .089 & & \\
\hline & Total & 23.333 & 95 & & & \\
\hline \multirow{3}{*}{ Age } & Between Groups & 65.260 & 26 & 2.510 & 7.616 & .000 \\
\hline & Within Groups & 22.740 & 69 & .330 & & \\
\hline & Total & 88.000 & 95 & & & \\
\hline \multirow{3}{*}{ Education } & Between Groups & 61.971 & 26 & 2.383 & 9.207 & .000 \\
\hline & Within Groups & 17.863 & 69 & .259 & & \\
\hline & Total & 79.833 & 95 & & & \\
\hline \multirow{3}{*}{ Experience } & Between Groups & 61.097 & 26 & 2.350 & 8.891 & .000 \\
\hline & Within Groups & 18.237 & 69 & .264 & & \\
\hline & Total & 79.333 & 95 & & & \\
\hline \multirow{3}{*}{ Position } & Between Groups & 124.899 & 26 & 4.804 & 5.608 & .000 \\
\hline & Within Groups & 59.101 & 69 & .857 & & \\
\hline & Total & 184.000 & 95 & & & \\
\hline \multirow{3}{*}{$\begin{array}{l}\text { Number of experience years in the } \\
\text { same position }\end{array}$} & Between Groups & 55.513 & 26 & 2.135 & 11.958 & .000 \\
\hline & Within Groups & 12.320 & 69 & .179 & & \\
\hline & Total & 67.833 & 95 & & & \\
\hline \multirow{3}{*}{ Industrial company age } & Between Groups & 33.871 & 26 & 1.303 & 7.117 & .000 \\
\hline & Within Groups & 12.629 & 69 & .183 & & \\
\hline & Total & 46.500 & 95 & & & \\
\hline \multirow{3}{*}{ Market orientation } & Between Groups & 7.286 & 26 & .280 & 6.015 & .000 \\
\hline & Within Groups & 3.214 & 69 & .047 & & \\
\hline & Total & 10.500 & 95 & & & \\
\hline \multirow{3}{*}{ Size of industry } & Between Groups & 12.299 & 26 & .473 & 3.613 & .000 \\
\hline & Within Groups & 9.034 & 69 & .131 & & \\
\hline & Total & 21.333 & 95 & & & \\
\hline \multirow{3}{*}{ Number of employees } & Between Groups & 37.229 & 26 & 1.432 & 2.347 & .003 \\
\hline & Within Groups & 42.105 & 69 & .610 & & \\
\hline & Total & 79.333 & 95 & & & \\
\hline \multirow{3}{*}{ Type of industry } & Between Groups & 15.028 & 26 & .578 & 8.299 & .000 \\
\hline & Within Groups & 4.806 & 69 & .070 & & \\
\hline & Total & 19.833 & 95 & & & \\
\hline
\end{tabular}

Note: $\alpha \leq 0.05$. 
Table 15. Correlation between Variables of the Study

\begin{tabular}{|c|c|c|c|c|c|c|}
\hline Factors & & $\begin{array}{l}\text { Supplier feedback } \\
\text { Just in time } \\
\text { delivery by } \\
\text { suppliers }\end{array}$ & $\begin{array}{c}\text { Supplier } \\
\text { development } \\
\text { Customer } \\
\text { involvement }\end{array}$ & $\begin{array}{c}\text { Facilitation of just in } \\
\text { time production } \\
\text { Supplier feedback }\end{array}$ & $\begin{array}{c}\text { Just in time } \\
\text { delivery by } \\
\text { suppliers } \\
\text { Supplier } \\
\text { development }\end{array}$ & $\begin{array}{c}\text { Customer } \\
\text { involvement }\end{array}$ \\
\hline \multirow{2}{*}{$\begin{array}{l}\text { Supplier feedback } \\
\text { Just in time delivery } \\
\text { by suppliers }\end{array}$} & $\begin{array}{c}\text { Pearson } \\
\text { Correlation }\end{array}$ & 1 & $0.252^{*}$ & $0.610^{* *}$ & $0.566^{* *}$ & $0.474^{* *}$ \\
\hline & Sig. (2-tailed) & ------ & 0.013 & 0.000 & 0.000 & 0.000 \\
\hline \multirow{2}{*}{$\begin{array}{c}\text { Supplier } \\
\text { development } \\
\text { Customer } \\
\text { involvement }\end{array}$} & $\begin{array}{c}\text { Pearson } \\
\text { Correlation }\end{array}$ & & 1 & $0.525^{* *}$ & 0.194 & $0.544^{* *}$ \\
\hline & Sig. (2-tailed) & & ------ & 0.000 & 0.059 & 0.000 \\
\hline \multirow{2}{*}{$\begin{array}{l}\text { Facilitation of just } \\
\text { in time production } \\
\text { Supplier feedback }\end{array}$} & $\begin{array}{c}\text { Pearson } \\
\text { Correlation }\end{array}$ & & & 1 & $0.389^{* *}$ & 0.515 \\
\hline & Sig. (2-tailed) & & & ------ & 0.000 & 0.000 \\
\hline \multirow{2}{*}{$\begin{array}{c}\text { Just in time delivery } \\
\text { by suppliers } \\
\text { Supplier } \\
\text { development }\end{array}$} & $\begin{array}{c}\text { Pearson } \\
\text { Correlation }\end{array}$ & & & & 1 & $0.503^{* *}$ \\
\hline & Sig. (2-tailed) & & & & ----- & 0.000 \\
\hline \multirow{2}{*}{$\begin{array}{l}\text { Customer } \\
\text { involvement }\end{array}$} & $\begin{array}{c}\text { Pearson } \\
\text { Correlation }\end{array}$ & & & & & 1 \\
\hline & Sig. (2-tailed) & & & & & ------ \\
\hline
\end{tabular}

Note: ${ }^{*}$ Correlation is significant at the 0.05 level (2-tailed).

${ }^{* *}$ Correlation is significant at the 0.01 level (2-tailed). 